\title{
Membrane Filtration of Lead, Cobalt, and Nickel in Water and Fertilizer Samples for Enrichment/Separation and Flame Atomic Absorption Spectrometric Determination
}

\author{
Mustafa Soylak ${ }^{\bullet}$ and Recep Altin \\ Erciyes University, Faculty of Sciences, Department of Chemistry, 38039, Kayseri, Turkey
}

\section{INTRODUCTION}

Due to the role and bioaccumulation of metal ions in humans, animals, and plants, and their potential health risks, trace metal analysis is an important part of environmental pollution studies (1-4). For example, excess levels of lead and nickel can become toxic for human life (5-6), while cobalt is a necessary mineral (7). Thus, the determination of trace metals in food and environmental samples is an important study of analytical chemistry (6-10).

Because of low cost and easy application, atomic absorption spectrometry (AAS) analysis is a widely used instrumental technique for lead determinations (11-14). The negative or positive interference of co-existing ions in AAS analysis is a main problem for researchers (15-19). Heavy metals are generally found at trace levels, particularly at less than the detection limits of AAS which is another problem for these types of determinations (20-24). Enrichment and separation combinations, such as solid phase extraction, cloud point extraction, co-precipitation, solvent extraction, etc., are widely used to solve these limitations of AAS detection (25-27).

Adsorption of metals, chelated on different kinds of membranes, is called "membrane filtration" (28-32) and has been widely used for the preconcentration and separation of metal ions at trace levels from environmental samples prior

\footnotetext{
*Corresponding author.

E-mail: soylak@erciyes.edu.tr

Tel: +903524374933
}

\begin{abstract}
A membrane filtration procedure based on the adsorption of 2-(5-bromo-2-pyridylazo)-5(diethylamino)phenol (5-BrPADAP) chelates of $\mathrm{Pb}(\mathrm{II}), \mathrm{Co}(\mathrm{II})$ and $\mathrm{Ni}$ (II) on a cellulose acetate membrane filter has been investigated. Determination of the analyte elements was performed by flame atomic absorption spectrometry. The effects of some parameters including $\mathrm{pH}$, amount of 5-Br-PADAP, etc., on the recovery of the analyte elements were investigated, including influences of some matrix ions.

The preconcentration factor found was 15 . The detection limits for lead, cobalt, and nickel were $15.6 \mu \mathrm{g} \mathrm{L}^{-1}, 8.9 \mu \mathrm{g} \mathrm{L}^{-1}$, and $19.5 \mu \mathrm{g} \mathrm{L}^{-1}$, respectively. The validation of the procedure was verified using the addition-recovery test for real samples and analyzing a certified reference material. The procedure was successfully applied to the determination of analyte ions in environmental samples, including natural water samples.
\end{abstract}

to their instrumental detection. Different kinds of membranes, including cellulose acetate and cellulose nitrate, are preferred for this purpose. However, according to our literature survey, the combination of 2-(5-bromo-2-pyridylazo)-5(diethylamino)phenol-cellulose nitrate membrane filter for the separation and enrichment of trace metal ions has not been reported.

In the present work, a novel and simple membrane filtration procedure has been established for the separation-preconcentration of lead(II), cobalt(II), and nickel(II) as their 2-(5-bromo-2-pyridylazo)-5(diethylamino)phenol in environmental samples. The analytical parameters of $\mathrm{pH}$, sample volume, and amount of 2-(5-bromo-2-pyridylazo)-5-(diethylamino)phenol used were optimized.

\section{EXPERIMENTAL}

\section{Instrumentation}

A PerkinElmer ${ }^{\circledR}$ Model 3110 atomic absorption spectrophotometer, equipped with PerkinElmer hollow cathode lamps and a $10-\mathrm{cm}$ air-acetylene burner, was used for the determination of the analyte elements (PerkinElmer, Inc., Shelton, CT, USA). All instrumental settings were used as recommended in the manufacturer's manual (Table I).

A pH meter, Nel pH-900 Model glass-electrode, was employed for measuring the $\mathrm{pH}$ values in the aqueous phase. An Erlenmeyer flask with a ground glass stopper was used for the membrane filtration procedure. All solutions were prepared using reverse osmosis ultrapure water, with a resistivity of $18.2 \mathrm{M} \Omega \mathrm{cm}^{-1}$ obtained with a Milli$\mathrm{Q}^{\mathrm{TM}}$ system (Millipore Corporation, France).

\section{TABLE I}

Instrumental Conditions for PerkinElmer 3110 Flame Atomic Absorption Spectrometer

Element Wavelength Lamp Current

\begin{tabular}{ccc} 
& $(\mathrm{nm})$ & $(\mathrm{mA})$ \\
\hline $\mathrm{Pb}$ & 283.3 & 13 \\
$\mathrm{Ni}$ & 232.0 & 23 \\
$\mathrm{Co}$ & 240.7 & 23 \\
\hline
\end{tabular}




\section{Reagents and Solutions}

High purity chemicals were used (E. Merck Darmstadt, Germany) without additional purification. All experiments were performed using doubly distilled deionized water. For preparation of the standard stock solutions with an analyte concentration of $1000 \mathrm{mg} \mathrm{L}^{-1}$, nitrate salt of lead (E. Merck, Darmstadt, Germany) was used in $1 \mathrm{~L}$ calibrated flasks with $1 \%$ of $\mathrm{HNO}_{3}$. All plastic and glassware was soaked and cleaned in dilute $\mathrm{HNO}_{3}(1+9)$, then rinsed with distilled water before use. The standard solutions used for the calibration procedures were prepared before use by dilution of the stock solutions with 1 mol L ${ }^{-1} \mathrm{HNO}_{3}$. Diluted standard and model solutions were prepared daily from the stock standard solutions. Highly pure compounds were used to prepare stock solutions of different elements.

Membrane filters were purchased from Osmonics (Westborough, MA, USA). A $0.1 \%(\mathrm{w} / \mathrm{v})$ solution of 2-(5-bromo-2-pyridylazo)-5-(diethylamino)phenol (Sigma Aldrich) was prepared daily in ethanol. The $\mathrm{pH}$ of the model solution was adjusted to $\mathrm{pH} 2-3$ with phosphate buffer, pH 4-5 with $\mathrm{CH}_{3} \mathrm{COO}-/ \mathrm{CH}_{3} \mathrm{COOH}$ buffer, and $\mathrm{pH}$ 6.5-7.5 with dihydrogenephosphate buffer. Certified reference materials (CRMs) used were GBW07425 (GSS-11) Soil (National Research Centre for Certified Reference Materials, P.R. China) and SPS-WW2 Wastewater (Spectrapure Standards AS, Oslo, Norway).

\section{Preconcentration Procedure}

An amount of 15-25 mL aqueous solution containing $20 \mu \mathrm{g}$ of lead(II), $10 \mu \mathrm{g}$ of nickel, and $10 \mu \mathrm{g}$ of cobalt ions was placed into a glass beaker, and $10 \mathrm{~mL}$ of buffer solution and 2-(5-bromo-2-pyridylazo)-5-(diethylamino)phenol solution were added. After 5 minutes, lead-2-(5-bromo-2-pyridylazo)-5- (diethylamino)phenol chelates were collected through a cellulose nitrate membrane filter of $0.45 \mu \mathrm{m}$ size and $47 \mathrm{~mm}$ diameter. The collection is performed very quickly by filtration under suction with an aspirator. Then the membrane was completely dissolved in $500 \mu \mathrm{L}$ concentrated nitric acid at $80{ }^{\circ} \mathrm{C}$ on a hot plate. The solution was evaporated to dryness. The residue was diluted to $5.0 \mathrm{~mL}$ with $1 \mathrm{~mol} \mathrm{~L}^{-1}$ $\mathrm{HNO}_{3}$. The analyte elements were determined by flame AAS.

\section{Application to Real Samples}

A $0.5 \mathrm{~g}$ amount of GBW 07425 (GSS-11) Soil certified reference material was digested with aqua regia (18 $\mathrm{mL}$ concentrated hydrochloric acid and $6 \mathrm{~mL}$ concentrated nitric acid) at room temperature, and then heated to $150^{\circ} \mathrm{C}$. After evolution of the $\mathrm{NO}_{2}$ fumes ceased, the mixture was evaporated to near dryness and mixed with $24 \mathrm{~mL}$ of aqua regia, and then again evaporated to dryness. After evaporation, $10 \mathrm{~mL}$ of distilled water was added and the sample mixed. The resulting mixture was filtered through a $589 / 3$ blue ribbon filter paper (B125 mm, Schleicher \& Schuell, Germany) and the filtrate diluted to $25 \mathrm{~mL}$ with distilled water. Then the procedure given in the "Preconcentration Procedure" section was applied. The final volume was completed to $5.0 \mathrm{~mL}$ with distilled water. The analytes in this solution were determined by FAAS.

A $50 \mathrm{~mL}$ amount of water sample or $5 \mathrm{~mL}$ of SPS WW2 wastewater certified reference material was taken into a beaker, and the $\mathrm{pH}$ of the sample adjusted to $\mathrm{pH} 7$ with the buffer solution. Then the separation/preconcentration study developed above was examined. The concentration of the analytes in the final solution was determined by FAAS.

A $1.0 \mathrm{~g}$ amount of fertilizer sample was digested with $10 \mathrm{~mL}$ distilled water. The resulting mixture was filtered through a 589/3 blue ribbon filter paper (B125 mm, Schleicher \& Schuell, Germany). The filtrate was diluted to $25 \mathrm{~mL}$ with distilled deionized water and the procedure described in the "Preconcentration Procedure" section applied. The analytes in the final solution were determined by FAAS.

\section{RESULTS AND DISCUSSION}

\section{Influences of $\mathbf{p H}$}

Because the $\mathrm{pH}$ of the working media in the separation and preconcentration studies is one of the key factors (33-38), the influences of $\mathrm{pH}$ on the recovery of lead(II), cobalt(II), and nickel(II) on a cellulose nitrate membrane filter were investigated in the $\mathrm{pH}$ range of 2.0-7.5 (Figure 1). The quantitative recoveries (>95\%) for the analyte elements were found at the $\mathrm{pH}$ range of 6.5-7.0. All subsequent studies were carried out at $\mathrm{pH} 6.5$.

\section{Amounts of Ligand}

The amount of ligand is also a critical parameter for the occurrence of metal chelates and adsorption of them on the adsorbent (39-43). The effects of the amount of 2-(5-bromo-2-pyridylazo)-5(diethylamino)phenol on the recovery of the analyte elements on the cellulose nitrate membrane filter were investigated in the ligand amount range of $0-2.5 \mathrm{mg}$ (Figure 2 ). The recoveries of the analytes on the membrane were quantitative in the $2.0-2.5 \mathrm{mg}$ range. All further work was performed with the addition of $2.0 \mathrm{mg}$ ( $2.0 \mathrm{~mL}$ of $0.1 \%$ (w/v) solution) of 2-(5-bromo-2pyridylazo)-5-(diethylamino)phenol.

\section{Effects of Sample Flow Rate}

The influences of the flow rate of the sample solution on the retention of the analyte elements were investigated in the $2.0-5.0 \mathrm{~mL} \mathrm{\textrm {min } ^ { - 1 }}$ range. The quantitative recovery 
values for the analyte elements were obtained in all working ranges. For all further work, $2.0 \mathrm{~mL} \mathrm{~min}^{-1}$ was selected as the sample flow rate.

\section{Effect of Sample Volume}

The sample volume is another key factor in the preconcentration studies to obtain high preconcentration factors (44-49). The influence of sample solution volume on the recovery of the analyte elements was investigated in the 25-200 mL range. Figure 3 shows the quantitative recoveries of $>95 \%$ for a sample volume of $75 \mathrm{~mL}$. In this experiment, a $75 \mathrm{~mL}$ sample solution was adopted for preconcentration of the analytes from water samples. The final volume was $5 \mathrm{~mL}$, and a preconcentration factor of 15 was obtained.

\section{Interfering Effects of Diverse Ions}

The negative or positive effects of the main components of real samples on the analyte signals for the spectroscopic determination are called "Matrix Effects" (49-53). Therefore, sample pretreatment is required prior to analysis to reduce matrix effects. The interfering

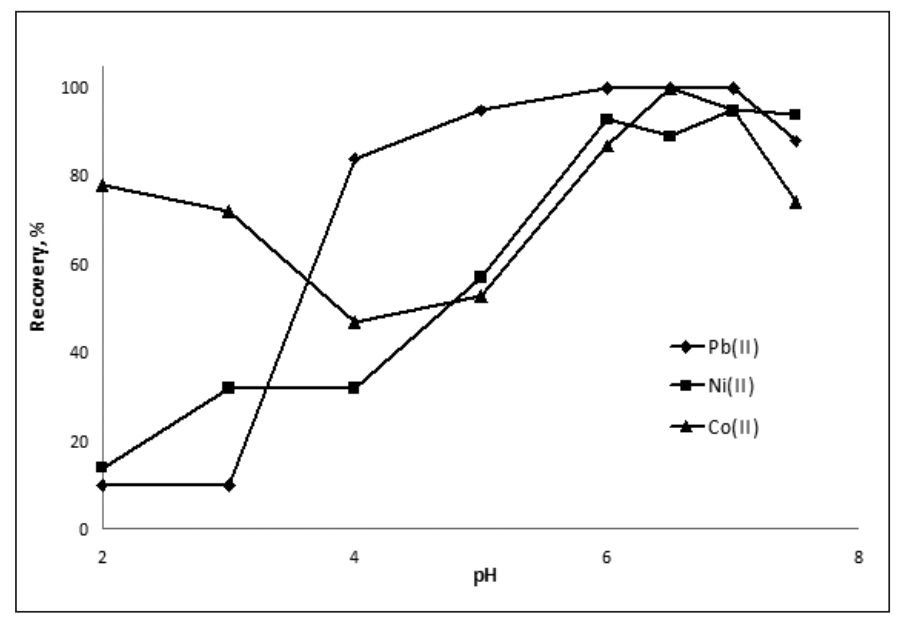

Fig. 1. Extraction percentage of $\mathrm{Pb}(\mathrm{II}), \mathrm{Ni}(\mathrm{II}), \mathrm{Co}(\mathrm{II})$ against $p H$.

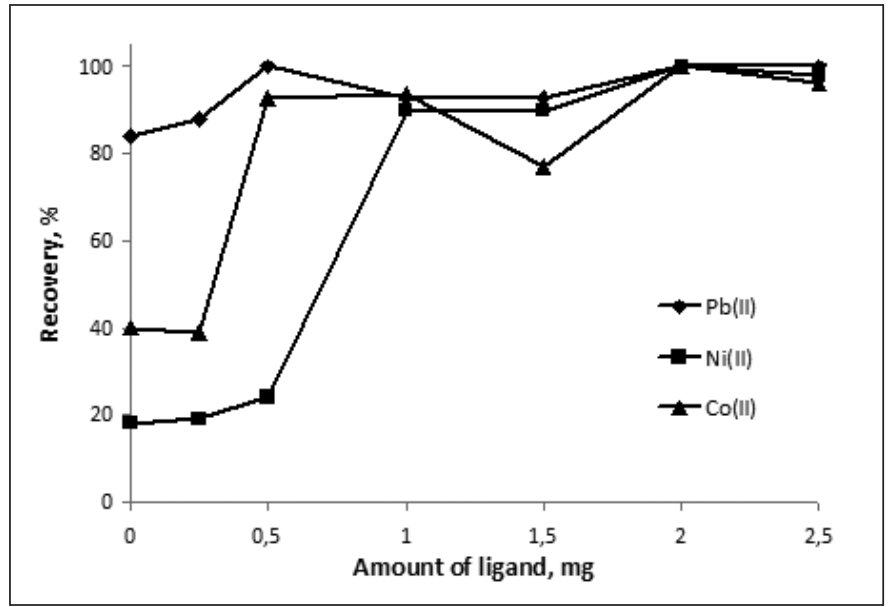

Fig. 2. Effects of amounts of 2-(5-bromo-2-pyridylazo)-5(diethylamino)phenol $(N=3)$. effects of diverse ions on the membrane filtration of the analyte elements were investigated. The results summarized in Table II show that the analyte ions can be preconcentrated effectively and the interference completely eliminated with the present method.

\section{Detection Limits}

The detection limits of the present method, evaluated as the concentration corresponding to three times the standard deviation of eight replicate measurements of the blank solution divided by the slope of the analytical curve $(3 \mathrm{Sb} / \mathrm{m})$, are listed in Table III. The relative standard deviation of the determinations was less than $6 \%$.

\section{Applications}

To estimate the accuracy of the procedure, different amounts of analyte elements were spiked in tap water, bottled water, and fertilizer samples and submitted to the preconcentration procedure. The results listed in Table IV show that good agreement was obtained between the added and measured analyte amounts. The recoveries calculated for the added standards were always higher than $95 \%$, thus confirming the accuracy of the procedure and its independence from matrix effects.

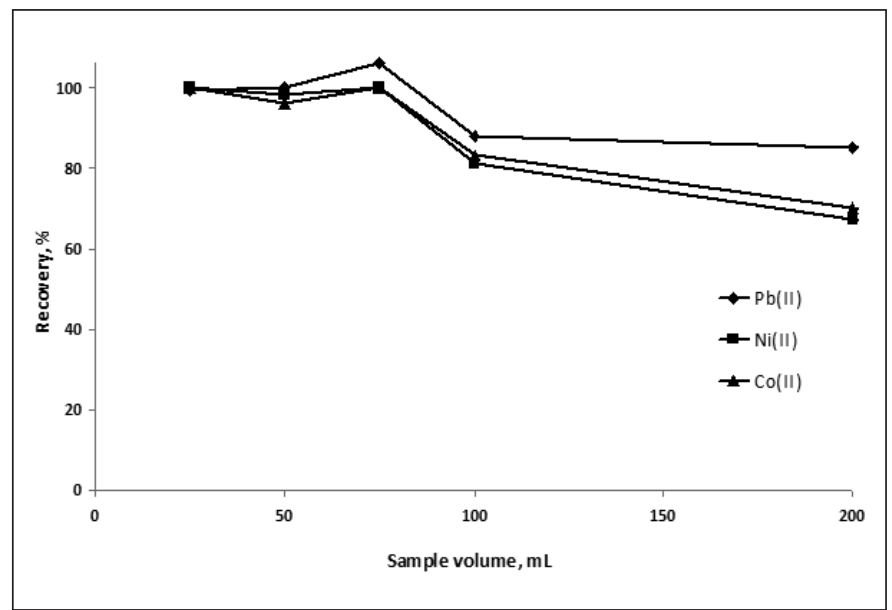

Fig. 3. Sample volume vs. recovery in the present membrane filtration procedure $(N=3)$. 
TABLE II

Interfering Effects of Various Ions ( $N=\mathbf{3})$

\begin{tabular}{|c|c|c|c|c|c|}
\hline \multirow[t]{2}{*}{ Diverse Ions } & \multirow[t]{2}{*}{ Added as } & \multirow{2}{*}{$\begin{array}{l}\text { Concentration } \\
\left(\mathrm{mg} \mathrm{L}^{-1}\right)\end{array}$} & \multicolumn{3}{|c|}{ Recovery (\%) } \\
\hline & & & $\mathrm{Pb}(\mathrm{II})$ & $\mathrm{Ni}(\mathrm{II})$ & $\mathrm{Co}(\mathrm{II})$ \\
\hline $\mathrm{Na}^{+}$ & $\mathrm{NO}_{3}^{-}$ & 10,000 & $97 \pm 1$ & $98 \pm 1$ & $95 \pm 2$ \\
\hline $\mathrm{K}^{+}$ & $\mathrm{Cl}^{-}$ & 15,000 & $97 \pm 0$ & $100 \pm 2$ & $96 \pm 2$ \\
\hline $\mathrm{Mg}^{2+}$ & $\mathrm{NO}_{3}{ }^{-}$ & 3000 & $97 \pm 0$ & $102 \pm 0$ & $95 \pm 4$ \\
\hline $\mathrm{Ca}^{2+}$ & $\mathrm{NO}_{3}^{-}$ & 750 & $98 \pm 1$ & $96 \pm 0$ & $100 \pm 0$ \\
\hline $\mathrm{Ni}^{2+}$ & $\mathrm{NO}_{3}^{-}$ & 25 & $95 \pm 1$ & - & $96 \pm 0$ \\
\hline $\mathrm{Pb}^{2+}$ & $\mathrm{NO}_{3}^{-}$ & 25 & - & $102 \pm 2$ & $96 \pm 4$ \\
\hline $\mathrm{Cu}^{2+}$ & $\mathrm{NO}_{3}{ }^{-}-$ & 25 & $103 \pm 1$ & $100 \pm 0$ & $100 \pm 2$ \\
\hline $\mathrm{Co}^{2+}$ & $\mathrm{NO}_{3}^{-}$ & 25 & $95 \pm 1$ & $98 \pm 2$ & - \\
\hline $\mathrm{Zn}^{2+}$ & $\mathrm{NO}_{3}^{-}$ & 25 & $103 \pm 1$ & $95 \pm 2$ & $96 \pm 4$ \\
\hline $\mathrm{Cl}^{-}$ & $\mathrm{K}^{+}$ & 15000 & $100 \pm 1$ & $100 \pm 2$ & $96 \pm 6$ \\
\hline $\mathrm{SO}_{4}{ }^{2-}$ & $\mathrm{Na}^{+}$ & 3000 & $100 \pm 1$ & $98 \pm 1$ & $98 \pm 4$ \\
\hline
\end{tabular}

TABLE IV

Addition/Recovery Tests for Real Samples (pH: 7.0, N=3)

\begin{tabular}{|c|c|c|c|c|c|c|c|}
\hline \multicolumn{2}{|c|}{ Analyte } & \multicolumn{2}{|c|}{ Tap Water } & \multicolumn{2}{|c|}{$\begin{array}{l}\text { Bottled Mineral } \\
\text { Water }\end{array}$} & \multicolumn{2}{|c|}{$\begin{array}{c}\text { Fertilizer (Mono- } \\
\text { potasium phosphate) }\end{array}$} \\
\hline & $\begin{array}{c}\text { Added } \\
(\mu \mathrm{g})\end{array}$ & $\begin{array}{r}\text { Found } \\
(\mu \mathrm{g})\end{array}$ & $\begin{array}{l}\text { Recovery } \\
(\%)\end{array}$ & $\begin{array}{l}\text { Found } \\
(\mu \mathrm{g})\end{array}$ & $\begin{array}{c}\text { Recovery } \\
(\%)\end{array}$ & $\begin{array}{l}\text { Found } 1 \\
(\mu g)\end{array}$ & $\begin{array}{l}\text { Recovery } \\
(\%)\end{array}$ \\
\hline \multirow[t]{3}{*}{$\mathrm{Pb}$} & 0.0 & $\mathrm{BDL}$ & - & $\mathrm{BDL}$ & - & BDL & - \\
\hline & 10.0 & $10.5 \pm 0.9$ & 105 & $10.1 \pm 0.4$ & 101 & $8.6 \pm 0.8$ & 86 \\
\hline & 20.0 & $20.8 \pm 2.5$ & 104 & $20.0 \pm 0.7$ & 100 & $16.2 \pm 0.8$ & 81 \\
\hline \multirow[t]{3}{*}{$\mathrm{Ni}$} & 0.0 & BDL & - & BDL & - & $3.4 \pm 0.6$ & - \\
\hline & 10.0 & $10.6 \pm 0.7$ & 106 & $9.7 \pm 0.2$ & 97 & $13.7 \pm 0.9$ & 102 \\
\hline & 20.0 & $19.8 \pm 1.1$ & 99 & $20.8 \pm 0.9$ & 104 & $23.5 \pm 0.5$ & 100 \\
\hline \multirow[t]{3}{*}{ Co } & 0.0 & $\mathrm{BDL}$ & - & $\mathrm{BDL}$ & - & GSA & - \\
\hline & 10.0 & $10.7 \pm 0.4$ & 107 & $9.7 \pm 0.8$ & 97 & $10.1 \pm 0.3$ & 101 \\
\hline & 20.0 & $19.0 \pm 0.4$ & 95 & $20.8 \pm 1.2$ & 104 & $20.4 \pm 0.0$ & 102 \\
\hline
\end{tabular}

BDL: Below the detection limit.

TABLE V

Application of Present Method to Certified Reference Materials (N: 5)

\begin{tabular}{|c|c|c|c|}
\hline \multicolumn{4}{|c|}{ SPS-WW2 Wastewater } \\
\hline & $\begin{array}{l}\text { Found by present } \\
\text { method }\left(\mu \mathrm{g} \mathrm{mL} \mathrm{mL}^{-1}\right)\end{array}$ & $\begin{array}{l}\text { Certified value } \\
\qquad\left(\mu \mathrm{g} \mathrm{mL} \mathrm{m}^{-1}\right)\end{array}$ & $\begin{array}{l}\text { Recovery } \\
(\%)\end{array}$ \\
\hline $\mathrm{Pb}$ & $0.48 \pm 0.40$ & $0.50 \pm 0.003$ & 96 \\
\hline $\mathrm{Ni}$ & $5.02 \pm 0.07$ & $5.00 \pm 0.03$ & 100 \\
\hline $\mathrm{Co}$ & $0.32 \pm 0.02$ & $0.30 \pm 0.002$ & 107 \\
\hline \multicolumn{4}{|c|}{ GBW 07425 (GSS-11) Soil } \\
\hline & $\begin{array}{l}\text { Found by present } \\
\text { method }\left(\mu \mathrm{g} \mathrm{mL} \mathrm{m}^{-1}\right)\end{array}$ & $\begin{array}{l}\text { Certified value } \\
\qquad\left(\mu \mathrm{g} \mathrm{mL} \mathrm{mL}^{-1}\right)\end{array}$ & $\begin{array}{l}\text { Recovery } \\
\text { (\%) }\end{array}$ \\
\hline $\mathrm{Pb}$ & $25.7 \pm 0.9$ & $24.7 \pm 1.4$ & 104 \\
\hline $\mathrm{Ni}$ & $24.7 \pm 1.3$ & $25.4 \pm 1.3$ & 97 \\
\hline $\mathrm{Co}$ & $11.0 \pm 0.4$ & $11.6 \pm 0.4$ & 95 \\
\hline
\end{tabular}

TABLE III

Limit of Detection for Analytes

\begin{tabular}{cc}
\hline Analyte & $\begin{array}{c}\text { Detection Limit } \\
\left(\mu \mathrm{g} \mathrm{L}^{-1}\right)\end{array}$ \\
\hline $\mathrm{Pb}$ & 15.6 \\
$\mathrm{Ni}$ & 19.5 \\
$\mathrm{Co}$ & 8.9 \\
\hline
\end{tabular}

The accuracy of the proposed procedure was evaluated by determining the analyte elements in certified reference materials SPS-WW2 Wastewater and GBW 07425 (GSS11) Soil. The results in Table V indicate that there is no significant difference between these results and the certified values, which confirms the suitability of the method for these types of samples.

The present membrane filtration procedure was also applied to the determination of analyte elements in different water and fertilizer samples. The results are given in Table VI. The levels of the analytes in the water and fertilizer samples were found at $\mu \mathrm{g} \mathrm{L}^{-1}$ and $\mu \mathrm{g} \mathrm{g}^{-1}$, respectively.

\section{CONCLUSION}

In the present work, the analytical potential of a cellulose nitrate membrane filter for the separation and preconcentration of lead(II), nickel(II), and cobalt(II) ions was investigated using natural water and fertilizer samples. The analyte ions were quantitatively recovered at $\mathrm{pH}$ 6.5. The detection limits for lead, cobalt, and nickel were 15.6 $\mu \mathrm{g} \mathrm{L}^{-1}, 8.9 \mu \mathrm{g} \mathrm{L}^{-1}$, and $19.5 \mu \mathrm{g} \mathrm{L}^{-1}$, respectively. The relative standard deviations of the determinations were less than $6 \%$. The effect of various experimental parameters such as $\mathrm{pH}$, sample flow rate and volume, and interfering ions on the retention of the analyte ions were investigated systematically. A 15-fold preconcentration factor was obtained. Thus, this method can successfully be used for the determination of lead, nickel, and cobalt levels in water and fertilizer samples. 
TABLE VI

Analyte Concentrations of Water and Fertilizer Samples Using Present Method ( $\mathrm{N}=3)$

\begin{tabular}{|c|c|c|c|}
\hline \multirow[b]{2}{*}{ Sample } & \multicolumn{3}{|c|}{ Concentration } \\
\hline & $\mathrm{Pb}$ & $\mathrm{Ni}$ & Co \\
\hline $\begin{array}{l}\text { Waste water from Akdagmagdeni, } \\
\text { Yozgat }\end{array}$ & BDL & $28.0 \pm 0.0 \mu \mathrm{g} \mathrm{L}^{-1}$ & BDL \\
\hline $\begin{array}{l}\text { Water from Yamula Dam Lake, } \\
\text { near Kayseri }\end{array}$ & BDL & BDL & $\mathrm{BDL}$ \\
\hline $\begin{array}{l}\text { Fertilizer (Monoammonium } \\
\text { phosphate) }\end{array}$ & N.D. & $4.6 \pm 0.0 \mu \mathrm{g} \mathrm{g}^{-1}$ & $1.7 \pm 0.0 \mu \mathrm{g} \mathrm{g}^{-1}$ \\
\hline Fertilizer (Nitrogen phosphor) & N.D. & $3.3 \pm 0.6 \mu \mathrm{g} \mathrm{g}^{-1}$ & $\mathrm{BDL}$ \\
\hline
\end{tabular}

BDL: below the detection limit.

\section{ACKNOWLEDGMENT}

The authors are grateful for the financial support of the unit of the scientific research projects of Erciyes University (FYL-2012-4113) (Kayseri, Turkey). Recep Altin thanks Erkan Yilmaz for his friendship and help during the experimental studies.

$\overline{\text { Received October 7, } 2013 .}$ 


\section{REFERENCES}

1. M. Soylak, D.S.K. Peker, and O. Turkoglu, Environ. Monit. Assess. 143, 267 (2008).

2. H. Hamaiedh and T. El-Hasan, Environ. Earth Sci. 62, 1771 (2011).

3. M. Tuzen and M. Soylak, Pol. J. Environ. Stud. 15, 915 (2006).

4. M.G. Yalcin and B. Unal, Asian J. Chem. 20, 3978 (2008).

5. M. Tuzen, S. Silici, D. Mendil, and M. Soylak, Food Chem. 103, 325 (2007).

6. Z. Ayas, G. Ekmekci, S.V. Yerli, and M. Ozmen, J. Environ. Biol. 28, 545 (2007).

7. M. Tuzen, E. Sesli, and M. Soylak, Food Control, 18, 806 (2007).

8. K. Saltali, D. Mendil, and H. Sari, Agrochimica 49, 104 (2005).

9. M. Soylak and, M. Dogan, Anal. Lett. 29, 635 (1996).

10. A. Aksoy, F. Duman, and G. Sezen, J. Freshwater Ecol. 20, 783 (2005).

11. M. Soylak, R. Saraymen, and M. Dogan, Fresen. Environ. Bull. 4, 485 (1995).

12. I. Narin, M. Soylak, L. Elci, and M. Dogan, Anal. Lett. 34, 1935 (2001).

13. Z.J. Li, Q.P. Peng, and H.X. Shan, J. AOAC Int. 90, 1191 (2007).

14. H. Owawa, T. Shimiza, and N. Uehara, Bunseki Kagaku 56, 721 (2007).

15. R. Saxena and A.K. Singh, Analyst 120403 (1995).

16. M. Tuzen, D. Citak, D. Mendil, and M. Soylak, Talanta 78, 52 (2009).

17. R. Biesuz, G. Alberti, and M. Pesavento, J. Solution Chem. 37, 5271 (2008).

18. L. Elci, M. Soylak, A. Uzun, E. Buyukpatir, and M. Dogan, Fresen. J. Anal. Chem. 368, 358 (2000)

19. S.M. Maliyekkal, K.P. Lisha, and T. Pradeep, J. Hazard. Mater. 181, 986 (2010).

20. I. Narin, M. Soylak, K. Kayakirilmaz, L. Elci, and M. Dogan, Anal. Lett. 36, 641 (2003).
21. M.R. Fathi, N. Pourreza, and Z. Ardan, Quim Nova 34, 404 (2011).

23. M. Soylak, L. Elci, and M. Dogan, J. Trace Microprobe Tech. 19, 329 (2001).

24. W.Z. Xu, S.L. Yu, A.Q. Liu, and Y.S. Yan, Spectrosc. Spectral Anal. 29, 522 (2009).

25. A. Duran, M. Tuzen, and M. Soylak, J. Hazard. Mater. 169, 466 (2009).

26. A. Moghimi, J. Korean Chem. Soc. 52, 140 (2008).

27. M. Soylak, U. Sahin, and L. Elci, Anal. Chim. Acta, 322, 111 (1996).

28 P.Y. Gao, X.X. Gu, and T.Z. Zhou, Anal. Chim. Acta 332, 307 (1996).

29. I. Narin and M. Soylak, Anal. Chim. Acta 493, 205 (2003).

30 C. Cpara, S. Hasegawa, and K. Naito, Anal.Sci. 19, 265 (2003).

31. M. Soylak, U. Divrikli, L. Elci, and M. Dogan, Talanta 56, 565 (2002).

32. A.U. Karatepe, M. Soylak, and L. Elci, Anal. Lett. 35, 1561 (2002).

33. F. Ashrafi, A. M. Attaran, and N.M. Kermani, J. Korean Chem. Soc. 52,133 (2008).

34. M. Soylak and L. Elci, J. Trace Microprobe Tech. 18, 397 (2000)

35. M.C. Yebra and R.M. Cespon, Atom Spect. 29, 27 (2008)

36. M. Soylak and M. Tuzen, J. Hazard. Mater. 152, 656 (2008).

37. Sh. Dehghan Abkenar, M. Hosseini and M. Salavati-Niasari, Asian J. Chem. 20, 4291 (2008).

38. F. Shah, T.G. Kazi, Naeemullah, H.I. Afridi, and M. Soylak, Microchem. J. 101, 5 (2012).

39. W.N.L. dos Santos, D.D. Cavalcante E. Galvao, P. da Silva, C.F. das Virgens, and F. de Souza Dias, Microchem. J. 97, 269 (2011).

40. F. Shah, M. Soylak, T.G. Kazi, and H.I. Afridi, J. Anal. Atom. Spect. 28, 601 (2013).

41. M. Alam, M. Aslam and S. Rais, Rasayan J. Chem. 2, 791 (2009).

42. M. Soylak, L. Elci, Y. Akkaya, and M. Dogan Anal. Lett. 35, 487 (2002).
43. A.R. Koohpaei, S.J. Shahtaheri, M.R Ganjali, A.R. Forushani, and F. Golbabaei, Iran. J. Environ. Healt. 5 , 283 (2008).

44. R.S. Praveen, P. Metilda, S. Daniel, and T.P. Rao, Talanta 67, 960 (2005).

45. S. Saracoglu, U. Divrikli, M. Soylak, and L. Elci, J. Food Drug Anal. 10, 188 (2002).

46. K.O. Saygi, M. Tuzen, M. Soylak, and L. Elci, J. Hazard. Mater. 153 , 1009 (2008).

47. O. Alp, H. Demiroz, O.Y. Ataman, and N., Ertas, Turk. J. Chem. 36, 247 (2012)

47. M. Tuzen, K.O. Saygi, and M. Soylak, J. Hazard. Mater. 156, 591 (2008).

48. M. Ghaedi, H. Tavallali, A. Shokrollahi, M. Zahedi, M. Montazerozohori, and M. Soylak, J. Hazard. Mater. 166, 1441 (2009).

49. A. Skwierawska, and E. Paluszkiewicz, Polish J. Chem. 82, 1219 (2008.)

50. N. Ozturk, V.N. Bulut, C. Duran, and M. Soylak, Desalination, 270 , 130 (2011).

51. N.L;.Dias, R.M. Costa, and G.L. Okajima, Separ. Sci. Technol. 43, 624 (2008).

52. M. Ghaedi, F. Marahel, A. Shokrollahi, M. Montazerozohori, and M. Soylak, Quim. Nova, 33, 404 (2010).

53. Z.A. ALOthman, M. Habila, E. Yilmaz, and M. Soylak, Atom. Spectroc., 34, 175 (2013). 